\title{
パラレルシンポジウム (1)
}

$\mathrm{C}$ 型肝炎ウイルスの基礎はどこまで解明されたか

6 月 24 日（木） 第 1会場（ホール A） 9:00〜11:00

司 会：三代 俊治（東芝病院 研究部）

林 紀夫（大阪大学 分子制御治療学） 


\section{C型肝炎ウイルスの基群はどこまで解}

明されたか (overview)

司会:三代伐治/林紀夫（柬芝病院研究部／大阪大學分子 制御治都)

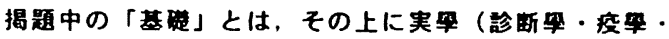

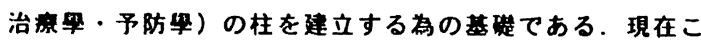
の「基磁」に阅し何か既解明で何か未解明なのか?

HCVは現今我国の肝疾㤩（特に肝症）の压倒的主原因て あり世罚的にもemergingしつつあることが既に解かって いる.これは新断學と疫學の成果であり，その基碀はHCV の寈伝俏分子生物学的技法で咀䏸することにより存外

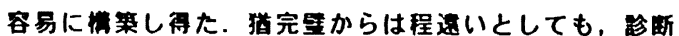
军・疫里の為の基硔を更に强化せねばとの火急の要器はな

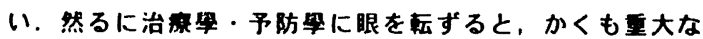
感染症でありながら我々は未だHCV-specificな抗ウイル ス用もワクチンも手にしていない，基群か足りないからで ある. 培美系不在の侭にこの方面の基确固めを試みること か如何に困維な事業であるかを，我々はHCVというゥイル スで初めて体聂させられているのかもしれない。しかし，

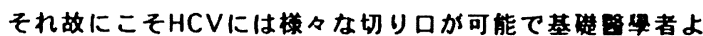

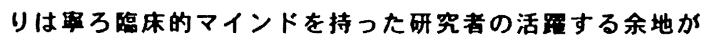
大きく残されている.

本シンポの侯䊖演題 23 題の多くは「ウイルス对宿主」の 問題を扱っていた．ウイルス㧡酸vs㴼主蛋白，ウ-蛋白vs 宿一核酸，ウ-蛋白vs宿-蛋白，ウ-抗原vs宿-免疫，etc..... 宿主本来の安定的タイナミスムの中に的入したウイルスは 㧻々な接点で宿主の動的内部と触れ合い，以て自己を利し 宿主を害する．分子レベルで此等接点のティティルを解明 することは，現时点では暗中楼索の钼あるも将来的には治

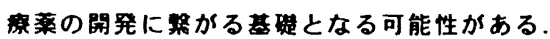

23题から以下8題を曹ら司会者の独断により選択した。 1 席:森庫等の「肝内脂算粗成」からは同著者等の既報（ Nature Medicine) の延長缐上でコア蛋白発現との関連を的 きたい，2席:加祽の「钿胞内経路活性化」もコア蛋白と の明連で興味がある. 3 席:竹上等の「NS3蛣合宿主蛋白」 と4席:山下等の「NS5B細胞内局在」の2題からは核内で生 起すらむHCV蛋白対宿主相互反店について示睖を得たい， 5 席:伊芸等の「二簀所のPTB桔合部位」と6席:本多等の 「钿胞周期云々」の2題からは料訳䛬節に间わるHCVの秘 技を明けるのではないか，7席:黑峙等の「NS5Aによる IFN-signal伝達抑制」は同著者等の別演题「PKRの発現」 とも閶連して注目.8席:林田等の「HLA非拘束性NS5A变 買」は前席の仕事に对しても教唆があり得て興味深い。
PaS-1-1 C 型肝炎における肝内脂質組成の特街 森屋恭爾 1 、等々力徹 ${ }^{2}$ 、新谷良澄1)、藤江肇" 堤武也 ${ }^{1.41}$ 、四柳宏 ${ }^{31}$ 、松浦善治4)、高山忠利 ${ }^{51}$ 、 渡辺清明 ${ }^{2)}$ 、幕内雅敏 ${ }^{5)}$ 、宮村達男 ${ }^{4)}$ 、木村哲 ${ }^{21}$ 、 小池和彦"

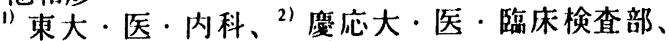

3) 聖マリ医大・内科、年感染研・ウイルス2部、

s) 東大 · 医 - 肝胆膵 - 外科

（目的）我々はC型朋炎肝組織の特徽の一つである steatosisがHCVコア蛋白によって直接ひきおこされて いる事をトランスジェニックマウスを用いて示した。 C型肝炎の病態における肝内脂質蓄積の意義を明らか にするため今回トランスジェニックマウス肺、ノント ランスジェニックマウス师、ヒトC型肝炎胿癌非癌部 肝組織、およびヒト大腸癌非癌部肝組織の各々につい て脂質組成を比較検討した。

(万法) HCVコア道伝子を発現するトランスジェニッ クマウス肺、ノントランスジェニックマウス胙、ヒト C 型肝炎朋癌朋切除症例非瘁部朋組織 (HBsAg陰性、 HCVAb陽性）、およびヒト大腸癌肝転移肝切除症例 非癌部川F組織（HBsAg陰性、HCVAb陰性）について 朋缄をホモジネート後、脂質を抽出した。抽出脂質に ガスクロマトグラフィーを行いコレステロールエステ ル、トリアシルグリセライド、リン脂質、遊離脂肪酸 各分画中の模成脂》酸を検出し比較検討した。

(絬果) マウス川Fではノントランスジェニックマウ ス群に此較しトランスジェニックマウス群においてコ レステロ-ルエステル、トリアシルグリセライド、リ

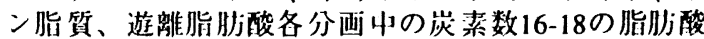
縕成が変化していた。特にステアリン酸に対するオレ イン酸の構成比率が増加していた。2）ヒト肝珹でも 炭素数 16-18の脂肪酸組成が各分画で変化していた。 コレステロ-ルエステル分画中のステアリン酸に対す るオレイン酸の構成此率がヒトC型朋炎奸痹肝切除症 例非癌部肝組織でヒト大腸癌肝枟移肝切除症例非㾔部 肝組織に比べマウス同栏增加していた。3）また朋缄 中の脂質量はヒト C 型肝炎症例で大腸癌症例に比べ増 加していた。

(結語）HCVコア遺伝子トランスジェニックマウス 肺に蓄積する北質には特徽がありヒトC型肝炎組織に おいても類似の特徽をもつことがコレステロールエス テル分画中であきらかとなった。脂肪酸の代謝反応に 阙与している可能性がトランスジェニックマウスのみ ならずヒト症例においても確認された。特にステアリ ン酸からオレイン酸への不飽和結合導入反応は細胞膜 の流動性の決定因子の一つである。トランスジェニッ クマウスを用いて C 型朋炎ウイルスの朋臟代謝経路へ の関与機序を解明することがC型旰炎ウイルスの病態 解明に重要であることが示唆された。 
PaS-1-2

培茫・分化に明わる钿胞内シクナル 伝逗 pathway を活性化するC 型肝炎ウイルス蛋白の 解析

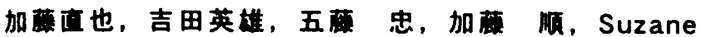
Ono-Nita，大塚基之，白带拣史，小俣政男

（東京大学消化器内科）

【目的】C 型肝炎ウイルス (HCV) RNA からは 1 つの 前㗨体蛋白が周訳され，留主およびイルスプロテア 一せにより切断されて，現在知られている限りで 10 のウイルス蛋白か産生される。これら HCV ウイルス 輩白か，MAPK カスケードを含む增厉・分化に的わる 4 和のシグナル伝逗 pathway を活性化するか否か换时 した.

【方法】哺轧類湅胞において CMV あるいは CAG プロ モーターにて各 HCV 蛋白（コア，NS2，NS3，NS4A， NS4B，NS5A，NS5B 計 7 玨）を発現する plasmid を 權整した。 これら HCV 蛋白発現 plasmidを HeLa 細胞 あるいは HepG2 湅胞に transfection し, serum response element (SRE), cyclic AMP response element (CRE)，あるいは activator protein-1 (AP-1) 結合配 列, serum response factor (SRF) 耛合配列の下流に ホタルルシフェラーゼ (Luc) をもつ plasmid を reporter として, 各湅胞内シグナル伝遣 pathway の活 性化につきルシフェラーセアアッセイにて検討した。す へての実段は transfectionの効率などを㭪正するため, シーパンジールシフェラーセ発現 plasmid cotransfectionし，インターナルコントロールとした.

【成费】コア蛋白は HeLa 湅胞において, CAG プロモ ーターを有するベクターのみを transfection した場合 のシーパンジールシフェラーゼ活性にて㭪正したホタ ルルシフェラーゼ活性を 1 とすると，SRE-Luc 活性を $4.9 \pm 3.6$ 倍， SRF-LUC 活性を $2.6 \pm 1.9$ 倍, AP1-Luc 活性を3.8土2.7 倍に活性化した。しかしなから， CRE-LUC 活性には影雷しなかった。 HepG2 細胞を用 いた結果も同機の䊅果であった。コア蛋白以外の HCV 蛋白は明らかな上粑頛胞内シクナル伝连 pathway の活 性化を示さなかった。

【考察】HCV 蛋白の中でもコア蛋白は增殖・分化に閶 わる MAPK カスケード (SRE-Luc, SRF-Luc)，JNK カスケード (AP1-LUC) を活性化することか明らかと なり、この活性化譏棈の詳耕を現在検对中である。
PaS-1-3

C 型肝炎ウイルス蛋白 NS3 と結合する宿主蛋白の検索 竹上 勉、蓮村 䇌

（金沢医大総医砳）

[目的］肝細胞密に進展する重要な要素にC 型肝炎ウイルス (HCV)持続感染がり、そこではウイルス蛋白と宿主蛋白との 相互作用が推定されているが、実態は不明である。我々は既に $\mathrm{HCV}$ 非橉造蛋白の NS3 が細胞形貿へ影䈏を及ほすこと、さら にp53 との相互作用について報告してきた。しかしながら、NS3 が直接的に結合する宿主蛋白については明らかではなかった。 ここでは睛母の 2 -ハイブリッドアッセイ系を用いてヒト cDNAライブラリーから HCV-NS3 結合蛋白質の検出を試みた。 [方法] HCV-NS3 のアミノ末端㑬(3354-4210 nt)をブラスミ ド pGBT9 内の GAL4 binding domain 下流に抑入し、融合蛋 白として発現するように模築した(pGBT-NS3N)。また NS3 内 のプロテアーゼ活性に関わる Ser $_{1165}$ を $\mathrm{Ala}_{1165}$ に圆き換えた変 翼 NS3 を組み込んだベクター(pGBT-NS3N-S1165A)も作成し た。また他方でヒト cDNAライブラリーを組み込んだフラスミ ド pGAD GH-HeLa cDNA を用意し、醉母 HFc に望入した。 スクリーニングは His-培地での発育及び LacZ 活性の有無で行 った。LacZ( $\beta$ ーガラクトシダーゼ)活性は 1 次スクリーニング では Hybond $N$ 上で行い、2 次スクリーニングは醭母を溶解し， 水溶液中で行った。䢙伝子解析は $\mathrm{ABI}$ Prism $^{\mathrm{TM}} 310$ を用いた。 [結果] His-培地でのスクリーニングで 288 個の His+クロー ンを得た。これらについて $\beta$ ーカララクトシターゼ活性をみたと ころ、15 クローンが陽性反応を示した。さらにそれらについ て再度、醭母に導入し、NS3N との結合の有無について愉討し た結果、8クローンに明確な陽性反応か示された。NS3NS1165A の場合も同等の結果であった。それらについて遺伝子 解析を行い、クローンNSP 7, 66 は SmD(small nuclear RNP) 、 クローン NSP99 は DNA helicase 及びクローン NSP34 は $\beta$ spectrin との相同性が確認された。しかしながら、他のクロー ンの場合は既知蛋白との相同性の無い未知蛋白であった。

[考察] 陽性クローンの遗伝子解析から HCV.NS3 と結合する 蛋白として、核内で作用する蛋白が浮かび上がってきた。それ らはプロテアーゼ活性あるいは活性域とは関係無くNS3 と結 合するようであるか、その強さ、あるいは機能との関わりにつ いては不明である。NS3 はある条件下ではその一部が核に移 行する可能性は既に示唆されており、ここで示された NS3 結 合核内蛋白と NS3 との共同作用及ひ宿主緗胞への愿管等の可 能性か推察される。今後、それら蛋白と NS3 との in virtroて の結合活性あるいは機能解析を行っていくことが必要である。 (なお本研究は金沢医大岩井潡研究員との共同研究である) 
PaS-1-4

\section{する領域の同定}

山下竜也 ${ }^{1}$, , 代田幸博 ${ }^{1)}$, 村上清史 ${ }^{2)}$, 金子周一 ${ }^{1)}$, 小林健一1)

(1) 金沢大学第一内科, ${ }^{2}$ 金沢大学がん研腫瘍分子)

【目的】 $\mathrm{HCV}$ の持続感染は慢性肝炎, 肝硬変を引き起こ し, 高率に肝癌を発生する. その持続感染の遮断は肝発癌 の予防につながると考えられる. その感染遮断の標的とし てウイルスの複製が挙げられるが，そのメカニズムについ ては培養細胞や実験動物を用いた感染系が十分に確立され ておらず未だ解明にはほど遠い状況である．我々はウイル ス複製酵素である RNA 依存性 RNA ポリメラーゼ活性を 持つNS5B を大腸菌 GST 融合蛋白を用いて精製しその活 性を示すこと成功し報告し，その精製段階でNS5B のC 末 端にアンカー領域を発見した(JBC, 273(25), 1998)

今回 NS5B とそのアンカー領域を欠損した NS5B(NS5Bt) の細胞内局在とそれに影響する領域について検討した.

【対象と方法】緑色営光蛋白(GFP)融合蛋白発現ベクター, pGFP を用い肝癌由来培養細胞, HLE 細胞に一過性発現し 細胞内局在を共焦点顕微鏡を用いて検討し, 種々の $\mathrm{N}$ 末端 $\mathrm{C}$ 末端の欠損変異，置換変異も用いて検討した．免疫染色 は 1 次抗体として核小体に対する抗体，2次抗体としてビ オチン標識ヤギ抗ウサギ IgG抗体を用いストレプトアビジ ン抱合テキサスレッドを用い視覚化し検討した。

【成績】NS5B 全長は細胞質内核膜周囲にみられ，その C 末端の 21 アミノ酸を欠損した NS5B(NS5Bt)は核内に塊 状のパターンを形成した. アンカー領域の置換変異である NS5B-m4, m5 も同様の核内移行を認めた. N 末端の欠損 はNS5B の局在に影響しなかったが，C 末端の欠損は局在 に影響した。 2951 残基以上の C 末端の欠損 NS5B は細胞 質びまん性にみとめ, 2955 残基は核内塊状形成を呈した。 2951〜2955 残基にはよく保存された塩基性と疎水性アミ ノ酸残基の繰り返し KLKLがあり,このアミノ酸残基の置 換変異についても検討した。核内塊状形成は核小体に対す る抗体を用いた免疫染色により核小体に一致することが判 明した。

【結語】 HCV NS5B 領域の C 末端にアンカー領域を発見 した. そのアンカー領域を欠損することにより核小体への 集積を観察し，その集積に影響する領域を限定した。この 欠損 NS5Bがウイルス感染細胞で認められるという事実は 報告されていないが，ウイルス複製酤素であるNS5Bが核 小体の因子と結合する可能性が考えられ， $\mathrm{HCV}$ 複製に関 する宿主細胞との関係を解明する糸口になるものと考えら れる.
PaS-1-5 HCV RNA 3'末端X領域及びコア蛋白領域の PTB結合性及びそのRNA䀳訳調節機棈

伊藤敬義")，三田村圭二"， Michael M.C. Lai ${ }^{2)}$

昭和大学第二内科"),

Howard Huges Medical Institute, 南カリフォルニア大 ${ }^{2)}$

[目的]C型肝炎ウイルス (HCV) ゲノムRNAの複製、梓訳 調節機構には種々の宿主因子が介在すると推測されてい る。我々は宿主因子の polypyrimidine-tract-binding protein (PTB)がHCV RNA 3' 末端のX領域に特異的に結合し，その $X$ 領域がHCVのinternal ribosome entry site (IRES) 依存性期 訳調節に関与していることを報告した (Ito and Lai, J.Virol. 71:8698-8706, 1997; Ito et al., J.Virol. 72: 8789-8796, 1998)。 我々はこの翻訳調節機構を解明する目的で, PTBの HCV RNAの 5'例領域（5'-UTR及びコア蛋白領域）との結合性 及びその結合部位のHCV RNA翻訳への関与を検討した。 [万法] UVクロスリンク法及びゲルシフト法を用いてHCV RNAとHeLa細胞抽出液内のPTB及び recombinant PTBとの 結合性を検討し、deletion mutantを用いて結合部位のマッピ ングを行った。更にHCV 5'-UTR、コア蛋白、3’-X領域遺 伝子及び reporterとしてルシフェレース遺伝子をもつキ メラHCV RNAと各PTB結合部位の deletion mutant RNAを T7 RNAポリメレースで合成した。次いで、各RNAの翻訳 効率をウサギ網状赤血球抽出液を用いた in vitro translation実験で比較した。

[成績] HCV 5'-UTR内IRESへのPTB結合性が報告されてい るが、今回の結果からは 5'-UTR内にPTB結合部位は認め なかった。一方、コア蛋白領域の3'末端に新たなPTB結合 部位を認めた。この結合部位は各genotypeで良く保存され たpyrimidineに富む領域であった。In vitro translation実験の 結果から、この領域を保持するRNAの翻訳効率は保持し ないRNAと比較し3-4倍低いことが認められた。しかし、 3'末端にX 領域を持つRNAで比較すると、このコア蛋白領 域内PTB結合部位による翻訳抑制効果は軽隇した。

[考案] HCV RNAには3’末端X領域、コア蛋白領域と少な くとも2力所のPTB結合部位が存在する。HCVゲム内に コア蛋白領域のPTB結合塩基配列が存在すると、HCV RNA翻訳は抑制される。この翻訳抑制は3'未端にX 領域が 存在すると軽減されることから、異なる二つのPTB結合部 位がPTBを介し、一方では翻訳増強に、他方では翻訳抑制 に作用し、ウイルスRNA翻訳調節に関与していると推測され た。

[結語] HCV RNAと宿主因子との相互作用の解明はウ似複 製、翻訳調節機構の解明、更に抗ウイル又薬の開発にとって重 要である。 
PaS-1-6 細胞周期と C 型肝炎ウイルス蛋白翻訳效率 本多政夫 "), 金子周一 "), Stanley M Lemon 2), 小林侹一"1) (1) 金沢大学第一内科, ${ }^{2)}$ Department of Microbiology and Immunology, The University of Texas, Medical Branch at Galveston)

【目的】C型肝炎ウイルス (以下 $\mathrm{HCV}$ ) の蛋白翻訳は 5' 非翻訳領域 (以下 5 'NTR) に存在する Internal ribosomal entry site (以下 IRES) によって行われる。 HCV の蛋白翻 訳効率を生理的条件下でモニターするため、HCV-IRES と レポーター遺伝子を恒常的に発現する細胞を樹立し、 様々な条件下で HCV-IRES 活性を測定した。

【方法】CMV プロモーターの下流に Renilla luciferase (Rluc), 5 'NTR, Firefly luciferase (F-luc) の順で Bicistronic な遺伝子を含むべクターを構筑した。このべクターを Huh-7 細胞に導入し上記遺伝子を恒常的に発現する細胞 (RCF-26) を樹立した。この細胞における R-luc 活性は細 胞のキャップ依存性蛋白翻訳効率を示し、F-luc 活性は HCV-IRES によるキャップ非依存性の蛋白翻訳效率を示 す。この細胞にCy cloheximide 処理、ポリオウイルス感染 を行い、また異なる細胞密度、血清濃度及び細胞周期に おけるそれぞれの R-luc、F-luc 活性を測定した。細胞周期 の同期は Aphidicolin により $\mathrm{G}_{1} / \mathrm{S}$ 期ブロック後、 Aphidicolin free 培地に変换して経洔的に細胞を採取し行 った。細胞周期は flowcytometry にて測定した。

【結果】Cycloheximide 存在下、両レポーター活性 (R-luc, F-luc) は同様に低下し細胞内での両レポーター蛋白の半 隇期は 6 時間であった。ポリオウイルス感染により R-luc は低下し、F-luc は上昇し、相対的 HCV-IRES 活性 (Fluc/R-luc) は上昇した。一方、細胞密度の上昇に伴い、 R-lucは上昇したが、F-luc は低下し、相対的 IRES 活性は

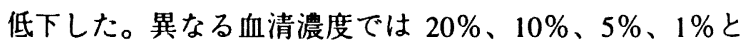
血清濃度の低下に伴い相对的 IRES 活性は低下した。細胞 周期との関連では HCV-IRES 活性は細胞周期依存性に変 化し、相対的 IRES 活性は合成期 $(S)$ 、分裂期 $\left(\mathrm{G}_{2} / \mathrm{M}\right)$ で高 く、休止期 $\left(\mathrm{G}_{0}\right)$ の約 5 倍の活性を示した。

【結語】 HCV-IRES 话性は細胞が休止期 $\left(\mathrm{G}_{0}\right)$ では低く、 增殖状態 $\left(S, G_{2} / M\right)$ では高いことが明らかとなった。正 常肝細胞の多くは $\mathrm{G}_{0}$ 期にあり、慢性肝炎状態では合成期 $(S)$ 、分裂期 $\left(\mathrm{G}_{2} / \mathrm{M}\right)$ の細胞が上昇することから HCV は慢 性肝炎状態での複製に有利な機構を有していると考えら れた。
PaS-1-7 C 型肝炎ウイルスNS5A蛋白によるインター フェロンシグナル伝達抑制機構の解析

東京医科苗科大学第二内科 '、同保健衛生学科 ${ }^{2}$ 、武蔵野 赤十字病院消化器科 ${ }^{3}$

黒崎雅之、榎本信幸、坂本直哉、前川伸战、永山和宜、

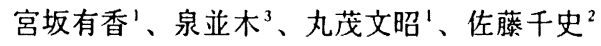

【目的】我々はNS5A領域内ISDR(NS5A 2209-2248)のアミ ノ酸変異と interferon (IFN)治療効果が関連することを報告 してきた。最近ISDRを含むNS5AのC末端領域が転写活性 化作用を有することがKatoらにより報告されたが、IFN治 療抵抗性との関連は現時点では明らかではない。一方、 NS5Aと同样に転写活性化作用を有寸る adenovirus E1A、 EB virus NA等のウイルス蛋白は、細胞内IFN signal伝達系 を阻害する作用を有することが知られている。今回我々 は、NS5A蛋白による細胞内IFN signal 伝達系への抑制効 果を解析し、同効果に対するISDRアミノ酸変異の影響を 検討した。

【方法】C型慢性肝炎症例の血清からRT-nested PCR法に よりISDRに種々の変異を有するNS5A遺伝子を増幅、

CMV Enhancer / Promoterの下流に組み込みNS5A 発現vector を作成した。さらにIFN誘導遺伝子のpromoter領域に存在 するIFN stimulated response element (ISRE)の下流に luciferase geneを組み込んだISRE-reporter vectorを作成し、 NS5A発現vectorとともにHuh- 7 細胞内にcalcium phosphate 法で遺伝于導入した。48時間培養後にIFN alpha 2b 100$1000 \mathrm{IU} / \mathrm{ml}$ で4-8時間刺激し、luciferase活性を测定した。

【成績】ISRE-reporter vectorを transfectionした細胞ではIFN 刺激によりluciferaseが誘導され、IFN dependentにluciferase が発現することが確認された。NS5A発現vectorのcotransfectionにより、IFNにより誘導されるluciferase活性は 8-53\%抑制された。IFN independentにluciferaseを強制発現 するvector、pGL3 controlをtransfectionした細胞において はNS5Aはluciferase発現に影響せず、NS5Aによるluciferase 活性の抑制はIFN signal伝達の阻害を反映していると考え られた。この抑制効果は、NS5A wild typeでは29-53\%で あったのに対し、ISDRに変異を有するNS5A intermediate およびmutant typeでは8-31\%であり、NS5A wild typeにお いてより強い抑制効果がみられた。

【結語】HCV-NS5A蛋白は、IFNにより誘導されるreporter geneの発現を抑制し、その効果はISDRの棈造と関連して いることが示された。NS5A蛋白によるIFN治療抵抗性の 機序として、細胞内IFN signal 伝達抑制機構が存在するこ とが示唆された。 
PaS-1-8

HLA非拘束性に生じるHCVの

NS5Aアミノ酸変異とIFN治療効果の関係

林田一洋"，木村洋一"，向出雅一"2，上野新子"，田中 博文"，石橋大海"，仁保喜之"

("九州大学第一内科, ${ }^{21}$ SRL株式会社)

【目的】 HCVの非構造領域の変異はCTLの制御を受 けていると考えられている。HCVのNS5Aの40アミノ 酸よりなる領域 (ISDR) とIFNの治療効果との関係が 報告されているが，そのアミノ酸变異の機序は明らか にされていない。我々は患者HLA class Iより予想さ れうるISDRアミノ酸配列上のHLA結合モチーフを調 べて, ISDR領域のアミノ酸変異におよほすCTLの影 響とIFNの治療効果の関係を検討した。

【方法】総投与量400MU以上のIFN- $\alpha$ 製郕を受けた 101名のHCV1bによるC型慢性肝炎患者を検討した。 患者血清中のHCVのISDR領域のアミノ酸配列は，榎 本らの報告に準じてdirect sequence法で決定し，ア ミノ酸の変異数に応じて wild (0), intermediate (1

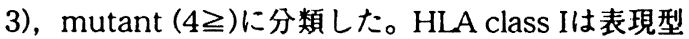
で決定し, HLA結合モチーフは遺伝子型または表現型 での報告を参考にし，ISDRアミノ酸配列上で可能性 があるものを採用した。

【成綪】101名のIFN治療結果はCR18名, TR 67名, NR 16名であった。ISDRのmutant typeでは有意に 血中HCV量が低值でIFNの治療効果も高かった。 ISDRアミノ酸変異に関しては，4番目から12番目 (ISDR4-12) と15番昌から40番日（ISDR15-40） では明らかに変異の頻度に差があり, ISDR4-12は intermediate typeおよびmutant typeいずれでも認 められるが, ISDR15-40はmutant typeで有意に增加 した。HLA class Iの特定のalleleと, 特定のアミノ酸 変異やIFN治療效果との関係は認められなかった。し かし個々の患者でのHLA結合モチーフを検討した結 果, ISDR4-12はHLA結合モチーフを含む可能性が極 めて低いのに対して，ISDR15-40はHLA結合モチー フを含む可能性が極めて高かった。多変量解析を行う と, ISDR4-12 と HCV RNA量のみがIFN治療勃果を 予測する有意な変数として導き出された。

【考案】ISDR4-12はHLA結合モチーフを含む可能性 が極めて低いためCTLのエピトープになる可能性は低 く，従って同部の変異はCTLが直接に影響をおよはさ ずに生じさせていると考えられた。しかし同部の変異 がIFN治療効果予測に重要であることから，NS5Aに 変異をもたらす細胞内の要因（NS5Aを含みNS5Aと 関連も持つウイルス蛋白や宿主側蛋白等) がIFN治療 効果に関係することが考えられた。

【結語】NS5AのISDRの4番目から12番目のアミノ酸 変異はCTLの直接作用で変巽した結果ではないにもか かわらずIFNの治療効果とは強く関係した。 